Stanisław Koziara

Uniwersytet Pedagogiczny im. Komisji Edukacji Narodowej w Krakowie

\title{
Miejsce i znaczenie protestanckich przekładów Pisma Świętego w historii polszczyzny biblijnej (zarys opisu)
}

\section{Uwagi wstępne}

Tyleż symboliczna, ile niecodzienna rocznica 500-lecia początków reformacji stwarza szczególną okazję, by na nowo spojrzeć na niektóre dokonania rodzimej myśli protestanckiej. Do tych najważniejszych bez wątpienia zaliczyć należy liczne inicjatywy przekładowo-biblijne, których pierwsze rezultaty na gruncie polskim datują się na połowę XVI stulecia. Ich głównym źródłem stało się, jak wiadomo, odwołanie w teologii ewangelickiej do fundamentalnej zasady doktrynalnej sola Scriptura, w Biblii postrzegającej jedyny autorytet w sprawach wiary. Równie podstawowe zalecenie protestantyzmu, aby każdy chrześcijanin docierał do źródeł swojej konfesji, mogło zostać zrealizowane tylko przez przybliżenie treści Pisma Świętego w drodze przekładu na język najbliższy wiernym, czyli język ojczysty. Temu zadaniu od początku przyświecała z kolei zasada ad fontes, tj. dyrektywa powrotu do źródeł, mająca na równi rangę teologiczną i filologiczną, dająca prymat w pracy przekładowej oryginalnym językom biblijnym, oddalając tym samym wszelkie w tym procesie pośrednictwo, jak chociażby wynikający z zaleceń Magisterium Ecclesiae katolicki autorytet Tradycji. Gruntem sprzyjającym tym nowatorskim, by nie powiedzieć rewolucyjnym zamierzeniom był duch ówczesnej epoki, wyrosły zarówno z idei oraz programu renesansowego humanizmu, jak też z niezwykle ważnego dla zamierzeń upowszechnienia treści biblijnych wynalazku druku.

Wystarczyło osiem dziesięcioleci - od połowy XVI do lat 30. XVII wieku, aby polska translatoryka biblijna wzbiła się na poziom iście europejski, w geometrycznym wręcz postępie pomnażając cały na tym polu dorobek wcześniejszych wieków [Leszczyński 2001: 133-142; Kwilecka 2003a: 209-230]. Dane mówią tu same za siebie: pięć pełnych przekładów Biblii, tj. Biblia Leopo- 
lity (1561)1, Biblia brzeska (1563), Biblia nieświeska (1572), Biblia Wujka (1599), Biblia gdańska (1632), osiem samodzielnych tłumaczeń Nowego Testamentu: Stanisława Murzynowskiego (1551-1553), Szarffenbergera-Bielskiego (1556), dwa osobne Szymona Budnego (1570, 1574), Marcina Czechowica (1577), ks. Jakuba Wujka (1593), tzw. rakowski (1606) oraz gdański (1606). Ponadto kilka pojedynczych tłumaczeń i parafraz Psałterza: Mikołaja Reja (1546?), Jakuba Lubelczyka (1558), Jana Kochanowskiego (1579), de facto dwa oddzielne Psałterze ks. Wujka (1594, 1599), a także Pawła Milejewskiego (1587) i Macieja Rybińskiego (1605), nie przywołując już z osobna przekładów niektórych wybranych ksiąg, kolekcji bądź pojedynczych psalmów licznie pomieszczanych w modlitewnikach, kancjonałach czy też katechizmach tamtego okresu [Buchwald-Pelcowa 1994: 243-262]. Niemal dwie trzecie tego dorobku stanowią inicjatywy wyrosłe w kręgu szeroko postrzeganych środowisk polskiej reformacji. Mówiąc o rodzimej spuściźnie protestantyzmu w dziedzinie translatoryki biblijnej, nie sposób pominąc także tych dokonań, które składają się na okres poreformacyjny i najnowszy. Mimo iż inny okazał się już charakter, a także inna dynamika owych prac, to jednak nadal można mówić o trwałej i w wielu dokonaniach nowatorskiej obecności w Polsce protestanckiej tradycji przekładowo-biblijnej, mierzonej inicjatywami zarówno całościowych, jak też częściowych tłumaczeń ksiąg biblijnych.

Ta jakże bogata seria przekładowo-biblijna składa się na wieloraki typ dziedzictwa, w którym osobne miejsce zajmuje jego wymiar filologiczny. Mówiąc najkrócej, bo nie miejsce tu na szczegółowe rozważania, trudno zrozumieć większość procesów rozwojowych w historii języka polskiego bez odwołania się do tego, co stanowi efekt oddziaływania i wpływów spuścizny rodzimej myśli reformacyjnej. Nie ulega najmniejszej wątpliwości, co też po wielekroć zostało udokumentowane, że tempo, rodzaj przemian i przewartościowań, jakich polszczyzna doświadczała w XVI stuleciu, były pochodną pojawienia się nurtów reformacyjnych i za ich przyczyną otwarcia się języka polskiego na nowe doświadczenia, skutkujące trwałym poszerzeniem jego potencjału na wszystkich poziomach systemu językowego: leksykalnym, frazeologicznym, składniowym, jak też stylistyczno-retorycznym [zob. m.in. Górski

$1 \mathrm{~W}$ toku opracowania posługuję się zwyczajowymi nazwami poszczególnych tłumaczeń biblijnych. Umieszczone przy tych nazwach lub osobno daty wskazują na rok pierwszego wydania przekładu. Dla celów prezentacji materiałowych wykorzystałem w części tradycyjne, drukowane edycje, a także wydania faksymilowe bądź też teksty tłumaczeń dostępne w bazach elektronicznych, w tym w szczególności przeglądarkę wersetów równoległych szesnastowiecznych polskich Ewangelii. Wykaz ekscerpowanych tekstów źródłowych znajduje się w części końcowej artykułu. 
1962: 233-279; Rospond 1962: 61-181; Kwilecka 2003b: 253-265; Winiarska 2004; Winiarska-Górska 2009: 279-312].

Zamierzeniem niniejszego opracowania nie jest próba całościowej rekapitulacji dość dobrze już dziś rozpoznanych zagadnień wpływu reformacji na dzieje kultury oraz języka polskiego, chodzi o zwrócenie uwagi na miejsce i znaczenie tej części dziedzictwa protestantyzmu, które obejmuje dokonania na polu translatoryki biblijnej, a ściślej rzecz biorąc roli owej spuścizny w kształtowaniu swoistych cech stylowych polszczyzny. Nie tylko przez wzgląd na ograniczenie gatunkowe zasadnicza uwaga w tym artykule spocznie na tym, co składa się przede wszystkim na staropolskie dziedzictwo biblijnej translatoryki protestanckiej i po części także katolickiej². W nieco mniejszym zakresie w perspektywie niniejszego ujęcia znajdą się zaś te dokonania, które obejmują nowszy dorobek rodzimych prac przekładowo-biblijnych powstały w różnorodnych środowiskach ewangelików polskich. Podjęta próba ma także po części za zadanie przywołanie oraz konfrontację dotychczasowych wyników badań w tym zakresie, niekiedy krytyczną ich cenę, w tym również odniesienie się do wcześniejszych rezultatów ujęć własnych. Przed przystąpieniem do zasadniczej części tak zaprojektowanego zadania badawczego konieczne jest sprecyzowanie tego, co współcześnie składa się na samo pojęcie oraz zakres cech tworzących rodzimy inwariant stylowy o proweniencji biblijnej.

\section{Polszczyzna biblijna - status i konstanty stylowe}

W rocznicę 500-lecia reformacji można powiedzieć, że zarówno filolodzy, jak i niemała część teologów-biblistów zgodni są co do tego, że w polskiej przestrzeni kulturowej wykształcił się na podstawie wielowiekowych doświadczeń językowo-literacki wzorzec stylowy, który przez jednych bywa nazywany polskim stylem biblijnym, przez innych określany jako polszczyzna biblijna. Mimo iż do drugiej z tych nominacji jest mi o wiele bliżej, to jednak nie istnieje, jak sądzę, szczególny rodzaj terminologicznego konfliktu w traktowaniu owych pojęć na prawach wymiennych, co też zaznaczy się w toku podjętych tu rozważań. Nie miejsce tu także na przybliżania szczegółowych kwestii definicyjnych i niekiedy odmiennych prób zakreślania tego, co składa się na językowe dziedzictwo polszczyzny biblijnej i jej swoistość na tle innych domen stylowych i tematycznych języka polskiego. W tej dziedzinie jako uprawniony przyjąć należy sąd, że tak status definicyjny, jak zakres referencyjny polszczyzny biblijnej w decydującej mierze jest pochodną odmiennej perspektywy widze-

2 Miano staropolski w niniejszym opracowaniu użyte zostało w znaczeniu bliższym ujęciom historycznoliterackim niż historycznojęzykowym. 
nia jej stylowych właściwości, które dają się rozpatrywać zarówno od strony teologiczno-biblijnej [Jezierska 2009: 9-17], literaturoznawczej [Głowiński $\mathrm{i}$ in. 1988: 496], jak i stricte lingwistycznej. Ta ostatnia z perspektyw zyskała w rodzimej refleksji próbę monograficznego ujęcia, w którym status stylowy polszczyzny biblijnej określony został z wykorzystaniem zaproponowanej przez Teresę Skubalankę koncepcji stylu jako rezultatu procesu konkretyzacji języka [Bieńkowska 2002]. Osobiście bliższe jest mi, wychodzące także z podstawy lingwistycznej, ujęcie integrujące do pewnego stopnia w syntetyczną całość owe perspektywy, z wyraźnym upomnieniem się o ten rodzaj spojrzenia na biblijne dziedzictwo polszczyzny, które w większym niż dotychczas stopniu uwzględnia retoryczny kontekst pochodzenia i ukształtowania wielu rodzimych biblizmów [Koziara 2009c: 21-31]. Także krąg denotacyjny tego, co kryje się pod pojęciem biblizm, mającym już dziś dość dobrze ugruntowany status terminologiczny, skłonny jestem w odróżnieniu od niektórych wcześniejszych propozycji rozszerzyć nie tylko na reprezentacje obejmujące jednostki i konstrukcje z poziomu leksykalnego, frazeologicznego oraz syntaktycznego, ale także na niektóre w pełni reproduktywne, samodzielne teksty oraz perykopy biblijne (np. Dekalog, Modlitwa Pańska) ${ }^{3}$.

Jak pokazują nowsze obserwacje, krąg inwariantnych stylowo płaszczyzn polszczyzny biblijnej dość wyraźnie odsłania teren spotkania się różnych tradycji, w którym obecność zaznaczają zarówno prymarne cechy języków biblijnych, obejmujące hebraizmy i grecyzmy leksykalne, frazeologiczne i składniowe, obok podobnej rangi wtórnych jednostek i konstrukcji powstałych już na gruncie języka polskiego, w tym także latynizmy i czechizmy biblijne [Koziara 2009b: 19-31]. Na taki kształt owych cech wpływ miał i w sporej części nadal ma fakt przemożnego udziału, głównie w obszarze rodzimych translacji katolickich, metody tłumaczeń wiernych, nierzadko dosłownych, w czym nie do końca, jak sądzę, należy upatrywać negatywnych skutków dla polszczyzny biblijnej, czy wręcz niekiedy określania owego zjawiska mianem „grzechu dosłowności”4. Godzi się bowiem zauważyć, o czym mowa będzie

3 Mowa tu o zaproponowanej przez Wojciecha Chlebdę definicji, która pojęciem biblizm nazywa ,jednostkę języka o dającym się ustalić pochodzeniu od tekstów biblijnych, niezależnie od swej postaci formalnej (wyraz - grupa - wyrazowa - zdanie) i statusu semantycznego kodowaną w pamięci językowej danego narodu i odtwarzaną w produkcji tekstów danego języka" [Chlebda 1998: 17]. Na fakt wielorakich możliwości definiowania i odniesienia tego terminu w polskiej literaturze zwraca uwagę najnowsze opracowanie Danuty Bieńkowskiej i Elżbiety Umińskiej-Tytoń [2017: 27-39].

4 Tym negatywnie wartościującym mianem opatruje Marek Piela znaczną część spośród współczesnych tłumaczeń Biblii na język polski [Piela 2003]. W kontekście genezy oraz 
jeszcze w dalszej części niniejszego opracowania, że swoistość polskiego stylu biblijnego bierze się właśnie z licznie „,inkorporowanych” do polszczyzny przekładowo-biblijnej elementów jej w znacznej mierze systemowo obcych, tj. rozlicznych kalk frazeologicznych i składniowych o proweniencji hebrajskiej, greckiej i łacińskiej (np. biblizmy odwzorowujące schematy: abstractum pro concreto, passivum divinum, participium graphicum), jak też równie częstych przeniesień na grunt polszczyzny figur oraz cech tekstowo-kompozycyjnych wywodzących się z tradycji retoryki semickiej (m.in. chiazm, hiperbola, waw narrativum, parallelismus membrorum). Rejestr tego, co składa się na zbiór konstant stylowych polszczyzny biblijnej, trudno jednakże zamknąć w obszarze raz ustalonych ilościowo wyznaczników. Różny też jest rezultat ich oceny w zależności od tego, która ze wspomnianych perspektyw towarzyszy owemu oglądowi.

Nie ulega wątpliwości, iż ostatnie dziesięciolecia, charakteryzujące się szczególną intensywnością w dziedzinie badań nad religijnymi refleksami w języku i literaturze polskiej, jeszcze bardziej wzmocniły przekonanie o istnieniu swoistych cech polszczyzny biblijnej. To efekt przede wszystkim szeroko zakrojonych prac materiałowo-porównawczych, których obiektem stały się zarówno całościowo widziane teksty przekładowe, jak też wybrane zagadnienia historycznojęzykowe oraz stylistyczne z obszaru rodzimej translatoryki biblijnej. W ich rezultacie do istniejących, klasycznych już dziś prac historycznojęzykowych, powstałych, co warto podkreślić, w niełatwym dla tego typu refleksji okresie powojennym, dołączyły w ostatnich dekadach nowsze studia nad dziedzictwem biblijnym polszczyzny, reprezentowane przez nader liczny zastęp historyków języka, badaczy dziejów i przemian szeroko pojętego polskiego języka religijnego ${ }^{5}$.

cech swoistych polszczyzny biblijnej w większym stopniu opowiadam się za stanowiskiem Marii Kosowskiej, która w werbalnej metodzie powojennych polskich tłumaczeń Biblii upatruje szeregu typowych wyznaczników polszczyzny biblijnej [Kossowska 1961: 5-32].

5 W poczet dokonań pierwszego pokolenia badaczy wliczają się głównie prace Ireny Bajerowej, Konrada Górskiego, Marii Kossowskiej, Mariana Kucały, Ireny Kwileckiej, Leszka Moszyńskiego, Ewy Ostrowskiej, Stanisława Rosponda oraz Stanisława Urbańczyka. Krąg nowszy zaś tworzą opracowania autorstwa m.in. Danuty Bieńkowskiej, Pawła Binka, Wojciecha Chlebdy, Marka Cybulskiego, Krystyny Długosz-Kurczabowej, Henryka Dudy, Jana Kamienieckiego, Danuty Kowalskiej, Stanisława Koziary, Tadeusza Lewaszkiewicza, Tomasza Lisowskiego, Arlety Łuczak, Bożeny Matuszczyk, Jolanty Migdał, Małgorzaty Nowak-Barcińskiej, Marka Pieli, Ewy Siatkowskiej, Joanny Sobczykowej, Bożeny Szczepińskiej, Bogdana Walczaka, Izabeli Winiarskiej-Górskiej, Ewy Woźniak oraz Andrzeja Zaborskiego. Zob. część bibliograficzna niniejszego opracowania. 
Osobną okazją do poszerzenia i ugruntowania refleksji nad historią i statusem polszczyzny biblijnej, a także swoistej „rewitalizacji” staropolskich przekładów Biblii, w tym głównie tłumaczeń protestanckich, okazała się międzynarodowa inicjatywa edycyjna „Biblia Slavica”, powstała przy znaczącym udziale polskich slawistów [Łuczak 2014: 135-150]. Przypomnijmy, że na rodzimą serię szeroko zakrojonej reedycji słowiańskich Biblii złożyły się trzy tłumaczenia protestanckie: Nowy Testament Stanisława Murzynowskiego (1551-1553), Biblia brzeska (1563), Biblia nieświeska (1572) oraz dwa katolickie: Biblia Leopolity (1561) oraz Biblia Wujka (1599). Wydaniom tym towarzyszą obszerne komentarze o charakterze językowym, kulturowym oraz teologicznym, w większości jednak opublikowane w wersji niemieckojęzycznej. Godzi się także przypomnieć, iż przed z górą dziesięciu laty udało się doprowadzić do jakże ważnej debaty teologiczno-filologicznej nad historią, kształtowaniem się i przemianami polszczyzny biblijnej, której to dyskusji pokłosie stanowi obszerna, wieloautorska publikacja [Koziara, Przyczyna, red. 2009b]. Wyniki owych prac nie tylko przyczyniły się do pomnożenia wiedzy na temat źródeł i historii biblijnej odmiany polszczyzny, ale też nierzadko radykalnie zmieniły wcześniej formułowane sądy i opinie na temat rangi i znaczenia owego dziedzictwa, roli i udziału w nim określonych tekstów przekładowych, w tym także rodzimego dorobku protestanckiej translatoryki biblijnej.

\section{Protestanckie tlumaczenia Pisma Świętego w dziejach polszczyzny biblijnej - zarys}

Pora przejść do syntetycznej próby spojrzenia na dorobek rodzimej translatoryki biblijnej widziany w perspektywie źródeł oraz kształtowania się cech swoistych polszczyzny biblijnej, a w szczególności oceny miejsca i znaczenia $\mathrm{w}$ tym procesie prac przekładowych powstałych w środowiskach polskich protestantów. Tak zakreślony zamiar badawczy, zdradzający w znacznym stopniu znamiona ujęcia monograficznego, w tym wypadku z konieczności ograniczony zostanie jedynie do zasygnalizowania ważniejszych stanowisk oraz przywołania wyników dotychczas prowadzonych pod tym kątem prac nad rodzimą spuścizną przekładowo-biblijną.

Mimo iż poruszany tu problem dotyczy w głównej mierze biblijnych translacji wyrosłych w środowiskach polskich protestantów, jako kluczowy w tych ocenach jawi się status katolickiej Biblii w przekładzie ks. Jakuba Wujka, a w szczególności całościowe jej wydanie z roku 1599, która na ponad trzy i pół wieku (366 lat) przejęła zadania tekstu niemal kanonicznego wśród katolików w Polsce. Owa wielowiekowa obecność w tej roli tłumaczenia Wujkowego, słusznie uznawana za fenomen niemal na skalę europejską, stworzyła 
uzasadnione podstawy do postrzegania tegoż przekładu jako fundamentu, na którym w naturalny sposób ufundowane zostały główne cechy polszczyzny biblijnej [Koziara 2013: 41-64; Walczak 2013: 65-81]. Nieco jednak w tle i przez długi czas niezbyt dobitnie w polskiej refleksji historycznojęzykowej zaznaczał obecność fakt, iż Wujkowe tłumaczenie Pisma Świętego stanowiło w istocie zwieńczenie najstarszej fazy w poszukiwaniach rodzimej szaty polszczyzny natchnionej. Brak tej perspektywy w niedostatecznym świetle stawiał wcale niemałe dokonania składające się na ,przedwujkową” serię tłumaczeń, zarówno średniowiecznych, jak i renesansowych; pomijano istotny czynnik ewolucji tego procesu, a także zależności warsztatu filologicznego i translatorskiego jezuity z Wągrowca względem dokonań jego poprzedników. Nie ulega zatem wątpliwości, że tyleż oczywistą, ile integralną częścią tej oceny stać się winna także kwestia postrzegania językowej strony Biblii Wujka w kontekście rozlicznych dokonań obozu reformacyjnego. Namacalnym świadectwem tego, że ks. Wujek nie tylko dobrze orientował się w dorobku na tym polu swoich antenatów, jak też korzystał z szeregu ich translatorskich pomysłów, jest fragment zamieszczony przez tłumacza w Przedmowie do własnego przekładu Nowego Testamentu:

Oprócz tekstu greckiego i łacińskiego miałem też przed oczyma wszytkie przekłady Nowego Testamentu polskie: krakowski, brzeski, nieświeski, Budnego i Czechowiców, a czasem też i czeski, które mi do obierania słów co nawłasniejszych polskich nie mało pomogły. [Wujek 1966: 67] ${ }^{6}$

Znaczenie osobne dla podjętych tu rozważań ma także nieco inny fragment z tejże samej Przedmowy, w której Wujek nie stroni od wartościującej oceny konkretnych tekstów przekładowych. Mowa tu o odniesieniu się do kalwińskiej Biblii brzeskiej z roku 1563, w którym to tłumaczeniu, mimo niepozbawionej ostrego tonu krytyki z pozycji konfesyjnej, tłumacz-jezuita potrafił dostrzec określone walory językowe, pisząc:

[...] po wydaniu Biblijej polskiej od katolików w Krakowie [Biblii Leopolity - S.K.] wnet nastała Biblija brzeska od kalwinistów przełożona, która jako gładkością polskiej mowy przechodzi krakowską. [Wujek 1966: 51]

6 Jak widać, ks. Wujek nie przywołuje w tej kolekcji Nowego Testamentu Murzynowskiego, którego to przekładu nie znał, o czym informuje w innym miejscu tejże samej Przedmowy [zob. Wujek 1966: 52]. 
Podjęte na szerszą skalę w ostatnich dekadach badania nad językową stroną renesansowej spuścizny przekładowo-biblijnej przynoszą wielorakie potwierdzenia owych zależności. Mowa tu o pracach nakierowanych na poszukiwanie międzytekstowych filiacji na płaszczyźnie leksykalnej, frazeologicznej oraz składniowej w obrębie XVI-wiecznych tłumaczeń biblijnych, w tym głównie powinowactw i zależności pomiędzy Biblia Wujka oraz starszymi przekładami tego okresu z kalwińską Biblia brzeska na czele.

Jedne z pierwszych ustaleń w tym względzie wyłaniają się z prac Danuty Bieńkowskiej, która, konfrontując warstwę leksykalną oraz frazeologiczną Ewangelii w przekładzie Jakuba Wujka z trzema innymi XVI-wiecznymi tłumaczeniami tej części Nowego Testamentu, tj. katolicką Bibliq Leopolity, kalwińską Biblia brzeska oraz ariańską Bibliq nieświeska, zgłosiła wiele ważnych argumentów językowych i translacyjnych, wskazujących na obecność we wszystkich tych translacjach wielu systemowych cech polszczyzny biblijnej [Bieńkowska 1992].

Podobne wnioski dają się wyprowadzić także z nowszej, odwołującej się do procedur stylometrycznych próby porównawczej oceny ilościowej i jakościowej leksyki Nowego Testamentu, podjętej przez Tomasza Lisowskiego w kontekście Biblii brzeskiej, Biblii Wujka, Nowego Testamentu gdańskiego oraz Biblii gdańskiej [Lisowski 2010].

Nader liczne powinowactwa odsłania także kontrastywne zestawienie tych miejsc tekstu brzeskiego z innymi przekładami XVI-wiecznymi, w których znajdują poświadczenia zasoby utrwalonych związków wyrazowych o typie frazeologizmów, paremii czy też stałych formuł o proweniencji biblijnej [Koziara 2015: 67-68; 2017: 162-164]. Osobną i wartą zauważenia grupę wśród owych biblizmów stanowią te, które początek w utrwalonej postaci biorą w tekście brzeskim, nieobecne jeszcze w tłumaczenia starszych, by następnie znaleźć kontynuację w przekładach późniejszych, w tym także w Biblii Wujka. Są wśród nich po dziś dzień jednostki mające status żywy, takie jak: jaskinia zbójców [Mt 21,13; Mk 11,17], Kamienie wotać będa [Łk 19,40], poruszyć niebo i ziemię [Ag 2,22], Lekarzu, uzdrów samego siebie [Łk 4,23], Nieobecny ciałem, ale obecny duchem [1 Kor 5,3], Szabat uczynion jest dla człowieka, a nie człowiek dla Szabatu [Mk 2,27], Znak, któremu się sprzeciwić będa [Łk 2,34], Żniwo wielkie, ale robotników mało [Mt 9,37; Łk 10,2].

$\mathrm{Z}$ dotychczasowych ustaleń wynika, że teksty brzeski i Wujkowy ujawniają także daleko idące podobieństwo w zakresie odwołania się do jednych z ważniejszych konstant stylowych polszczyzny biblijnej, jakimi są składniowe konstrukcje z użyciem imiesłowu przysłówkowego współczesnego oraz uprzedniego. Mowa tu zarówno o strukturze wypowiedzenia złożonego z imie- 
słowowym równoważnikiem zdania, jak też o wywodzących się z hebrajszczyzny biblijnej konstrukcjach opisowych zwanych participium graphicum [Siatkowska 2013: 39-54].

Równie interesująco przedstawiają się wyniki konfrontacji nacechowanych stylowo płaszczyzn języka Wujkowego przekładu Biblii z roku 1599 z tekstem o 33 lata młodszej protestanckiej Biblii gdańskiej. Zauważone już z górą pół wieku temu przez Marię Kossowską powinowactwa w zakresie kształtowania warstwy stylistyczno-językowej tych dwóch thumaczeń [Kossowska 1969: 85-112] poczęły zyskiwać z czasem potwierdzenie w kolejnych ujęciach porównawczych [Bieńkowska, Umińska-Tytoń 1994: 7-15; Koziara 2002: 69-80; Matuszczyk 2002: 81-86]. Z przywołanych już uprzednio nowszych badań Lisowskiego, ukierunkowanych na porównawczą analizę leksyki nowotestamentowej Biblii gdańskiej z wcześniejszymi tłumaczeniami tej części Biblii, dość jednoznacznie wynika, że tekst gdański, mimo odmienności doktrynalnych i innej podstawy źródłowej, zdradza o wiele większe zależności intertekstowe z tłumaczeniem Wujka niż ze swoją konfesyjną poprzedniczką, tj. Nowym Testamentem Biblii brzeskiej [Lisowski 2010: 435]. Najszerzej zaś jak dotąd zakrojone badania, jakie podjęła Maria Marzena Szurek, mające na celu konfrontację warstwy utrwalonych połączeń wyrazowych oraz inwariantnych stylowo cech składniowych w przekładzie Biblii Wujka i Biblii gdańskiej, jeszcze dobitniej potwierdziły te filiacje i zależności [Szurek 2013]. Przykładowe zestawienie paralelnych miejsc obydwu przekładów, w których zaznaczają obecność tego typu biblizmy, pokazuje nierzadko identyczne wręcz konstrukcje: Boże mój, Boże mój, czemuś mię opuścit? [Mt 27,46; Mk 15,34], Co tedy Bóg złączyl, czlowiek niechaj nie rozłacza [Mt 19,6; Mk 10,9], dzień sadny [Mt 10,15], glos wolajacego na puszczy [Mt 3,3; Mk 1,3; Łk 3,4], Godzien jest robotnik zapłaty swojej [Łk 10,7], grzechy młodości [Ps 25,7], Królestwo moje nie jest z tego świata [J 18,36], płacz i zgrzytanie zębów [Łk 13,28], rozdzierać szaty [Kpł 10,6], wierzgać przeciw ościeniowi [Dz 26,14].

Zależności i pokrewieństwa te równie mocno zaznaczają się na płaszczyźnie szerszych reprezentacji tekstowych, czego wymownym przykładem jest niemal całkowicie zbieżny kształt językowy Modlitwy Pańskiej [Mt 6,9-13] obydwu tłumaczeń:

Ojcze nasz, któryś jest w niebiesiech: Święć się imię Twoje. Przydź królestwo twoje. Bądź twa wola jako w niebie, tak i na ziemi. Chleba naszego powszedniego daj nam dzisia. I odpuść nam nasze winy, jako i my odpuszczamy naszym winowajcom. I nie wwódź nas w pokuszenie. Ale nas zbaw ode złego. (1599) 
Ojcze nasz, któryś jest w niebiesiech: Święć się imię Twoje. Przydź królestwo twoje. Bądź wola twa jako w niebie, tak i na ziemi. Chleba naszego powszedniego daj nam dzisia. I odpuść nam nasze winy, jako i my odpuszczamy naszym winowajcom. I nie w wódź nas na pokuszenie. Ale nas zbaw ode złego. (1632)

Na podobne, bardziej całościowe ujęcia porównawcze oczekują inne staropolskie przekłady Biblii. Z dotychczas poczynionych prób opisu pod kątem wybranych zagadnień językowych dość jednoznacznie wynika, że proces wykształcania się ponadindywidualnych cech powszechnie uważanych za konstanty polskiego stylu biblijnego daje wyraźnie o sobie znać już w okresie licznie podejmowanych prac przekładowych doby reformacji i kontrreformacji [Winiarska-Górska 2009: 311]. Jako potwierdzenie tego procesu niech posłuży, sondażowe jedynie, zestawienie paralelnych miejsc przekładowych XVI-wiecznych tłumaczeń nowotestamentowych katolickich i protestanckich, w których pojawiają się niemal w pełni zgodne podstawienia leksykalne w odniesieniu do form, które po dziś dzień uchodzą za jednostki mające status stylowo nacechowany, jak np.:

biada [Łk 11,52]: 1553; 1556; 1561; 1563; 1570;1572; 1577; 1593; 1599; 1632

brzemie [Łk 11,46]: 1556; 1561; 1563; 1570;1572; 1577; 1593; 1599; 1632 [ciężar: 1553]

dziedzictwo [Mk 12,7]: 1553; 1556; 1561; 1563; 1570;1572;1577; 1593; 1599; 1632

taknać [Mt 12,3]: 1551; 1553; 1556; 1570;1572; 1577; 1593; 1599; 1632 [chcieć jeść: $1561 ; 1563]$

rzec [Mt 9,37]: 1551; 1553; 1556; 1561; 1563; 1577; 1593; 1599; 1632 [mówić: $1570 ; 1572]$

pojmawszy [Mk 12,3]: 1561; 1563; 1577; 1593; 1599; 1632 [pochwyciwszy: 1553; jawszy: 1556; 1570; 1572]

zaprawde $[\mathrm{J} 1,51]: 1553 ; 1556 ; 1561 ; 1563 ; 1577 ; 1593 ; 1599 ; 1632$ [prawdziwie: 1570; 1572] 
O tym, że obecność tego rodzaju biblizmów w thumaczeniach tamtego okresu oznaczało świadome sięganie po repertuar jednostek stylowo nacechowanych, świadczy najlepiej fakt, iż w zasobach polszczyzny XVI i początków XVII wieku pojawia się wiele form względem owej leksyki synonimicznych. Przykładowo, mający podówczas już wyraźny odcień stylowy rzeczownik brzemię pozostawał w relacji bliskoznacznej do form: ciężar, ciężkość, jarzmo, obciązenie [SXVI, t. 2: 471], z których pierwsza, jak widać z przytoczonego powyżej materiału, znalazła zaledwie pojedyncze poświadczenie w jednym z tłumaczeń XVI-wiecznych (Murzynowski).

Bardzo podobne wyniki przynosi obserwacja XVI-wiecznych tłumaczeń ewangelicznych pod kątem realizacji tych jednostek, które współtworzą warstwę utrwalonych połączeń wyrazowych o typie frazeologizmów, paremii czy też stałych formuł wyrazowych, tworzących w opinii wielu badaczy centrum pośród ogółu biblizmów polszczyzny [Chlebda 2005: 209-251; Godyń 2006: 6-18; Długosz-Kurczabowa 2007: 155-174; Koziara 2009a]. I w tym przypadku zestawienie paralelnych miejsc $\mathrm{w}$ odmiennych w swych podstawach źródłowych i konfesyjnych tłumaczeniach protestanckich oraz katolickich pokazuje, iż mamy do czynienia z wyraźnie zaznaczonym procesem świadomego doboru form o ustabilizowanym statusie stylowym. Oto kilka przykładów spośród o wiele liczniejszego zasobu miejsc tekstowych:

Albowiem wiele jest wezwanych, ale / lecz mało wybranych [Mt 22,14]: 1551; $1553 ; 1556 ; 1561 ; 1563 ; 1577 ; 1593 ; 1599 ; 1632$ [Wiele bo jest wezwanych mato zaś wybranych: $1570 ; 1572]$

Boże mój, Boże mój, czemuś mię opuścit? [Mk 15,34]: 1553; 1556; 1563; 1570; $1572 ; 1593 ; 1599 ; 1632$

chleb powszedni [Mt 6,11]: 1551;1553; 1556; 1561; 1563; 1577; 1593; 1599; 1632 [chleb powszedzienny: 1570; 1572]

glos wołajacego na puszczy [Mt 3,3]: 1551; 1553; 1556; 1561; 1563; 1577; 1593; 1599; 1632 [glos wotajacego na pustyni: 1570; 1572]

Królestwo moje nie jest $z$ świata tego // tego świata [J 18,36]: 1553; 1556; $1561 ; 1563 ; 1570 ; 1572 ; 1577 ; 1593 ; 1599 ; 1632$

Lekarzu ulecz / uzdrów samego siebie [Łk 4, 23]: 1556; 1563; 1577; 1593; $1599 ; 1632$ 
Pokój temu domowi [Łk 10,5]: 1553; 1556; 1561; 1563; 1577; 1593; 1599; 1632 [Pokój domowi temu: 1570; 1572]

Proście, a będzie wam dano. Szukajcie, a najdziecie. Kołaccie, a będzie wam otworzono [Mt 7,7]: 1551; 1553; 1556; 1561; 1563; 1577; 1593; 1599; 1632

sól ziemi [Mt 5,13]: 1551; 1553; 1556; 1561; 1563; 1577; 1593; 1599; 1632 [sól ziemna: 1570; 1572]

żywot wieczny [J 3,16]: 1553; 1556;1561; 1563; 1570;1572;1577; 1593; 1599; 1632

Ujawnianie się wspólnostylowych tendencji dość dobrze ilustrują także pierwsze próby opisu właściwości składniowych XVI-wiecznych Biblii. Mowa tu m.in. o tych wyznacznikach polszczyzny biblijnej, które dotyczą nietypowego dla polszczyzny ogólnej i tym samym stylowo nacechowanego postpozycyjnego uszeregowania zaimka dzierżawczego względem rzeczownika, licznie obecnych biernych konstrukcji syntaktycznych (tzw. passivum divinum) czy też starannie zachowanego $\mathrm{w}$ większości tłumaczeń tego okresu paraleliczno-anaforycznego toku składniowego, określanego roboczo jako tzw. styl kai [Kępińska, dostęp: 2018]. Na marginesie warto dodać, że niemal wszystkie z przywołanych tu cech składniowych polszczyzny biblijnej rodowód biorą z systemowych cech języków biblijnych [Czerski 1997: 335-341].

Wskazane powyżej znamiona polszczyzny biblijnej dają się także rozpatrywać w kontekście równie wyrazistej cechy, która ujawnia się już w obszarze średniowiecznych przekładów Pisma Świętego. Mowa tu o swoistej tendencji do sięgania po formy w owym czasie recesywne, wręcz świadomej archaizacji języka przekładu, co w efekcie czyni tego rodzaju konserwatyzm jedną z konstytutywnych właściwości polskiego stylu biblijnego [Migdał, Piotrowska 2009: 313-322].

Wskazane procesy unifikujące zasoby polszczyzny biblijnej nie oznaczały bynajmniej, iż tym tendencjom w jednakowym stopniu ulegali thumacze Pisma Świętego interesującej nas tu głównie doby renesansu i początków XVII stulecia. Jak wynika już chociażby z przywołanych powyżej próbek materiałowych, owej zasadzie uszanowania wspólnego wzorca języka biblijnego zazwyczaj programowo nie poddawał się Szymon Budny, czołowy reprezentant obozu antytrynitarskiego, uzasadniając po części owo odstępstwo w przedmowie do swojego przekładu Pisma Świętego: 
Wiem, iż naszy Polacy pospolicie onej krainy mowy w pisaniu używają, z której kto rodem. Lecz ja nie trzymałem się tego zwyczaju. Bo ponieważ się to nie jednej której krainie, abo powiatowi, ale wszem przekładało, przeto też żadnemi własnościami mów nie brakowaliśmy. Znajdziesz tu słowa wielgopolskie, znajdziesz Krakowskie, Mazowieckie, Podlaskie, Sęndomirskie a bez mała i Ruskie. Głupstwo to jest mową jednej krainy gardzić, a drugiej słówka pod niebiosa wynosić. [Budny 1994: 17]

Także dotychczas poczynione obserwacje językowo-translacyjnych właściwości warsztatu przekładowego innych polskich Biblii okresu reformacji i kontrreformacji odsłaniają wiele świadectw otwarcia się ówczesnych tłumaczy na nowe zasoby polszczyzny, włączania w krąg rodzimych ekwiwalentów języków biblijnych zasobów mowy żywej, nierzadko o regionalnej, jak wynika z deklaracji przekładowej Budnego, proweniencji. Jak pokazują podjęte badania, to głównie w języku tłumaczeń protestanckich tamtego okresu mamy do czynienia ze spotkaniem się nowatorskich tendencji odwołujących się do humanistycznych zasad traktowania tekstu biblijnego z w pełni reformacyjną dyrektywą wyjścia naprzeciw szerokim potrzebom i możliwościom ówczesnego odbiorcy słowa natchnionego [Kwilecka 2003d: 335-352; Koziara 2017: 158-169].

W tym miejscu godzi się powrócić raz jeszcze do powszechnie znanego i przywołanego tu uprzednio faktu wyjątkowej pozycji obydwu przekładów Wujkowego i gdańskiego - w dziejach nie tylko polszczyzny biblijnej. Nie sposób bowiem zapomnieć, że w wypadku całościowego wydania Biblii Wujka z roku 1599 mowa jest o przekładzie, którego kształt językowy w znacznym stopniu stanowił efekt ingerencji cenzorskich jezuickiej komisji z ks. Stanisławem Grodzickim na czele. Mimo braku pełnej zgody wśród badaczy co do skali i skutków owych ingerencji, wiadomy pozostaje ich kierunek, tj. chęć uczynienia pełnej edycji Biblii Wujka o wiele bardziej zgodnej nie tylko z duchem, ale też z literą Hieronimowej Wulgaty. Efekty owych ingerencji dobrze znane są w świetle porównań tłumaczeń Nowego Testamentu (1593) i Psałterza (1594) wydanych za życia ks. Wujka z analogicznymi częściami pełnej, pośmiertnej edycji Biblii. W myśl tych ustaleń w bardzo wielu wypadkach ingerencje oznaczały dość mechaniczne naśladowanie łacińskiego wzorca, kosztem prób większego przybliżenia języka przekładu do przeżywającej renesansowy rozkwit polszczyzny [zob. m.in. Kossowska 1968: 355-360; Frankowski 1974: 63-83]. Wstępne ciągle próby oceny owych zmian pod kątem konstant polszczyzny biblijnej pokazują, że korekty cenzorskie w wielu 
miejscach skierowały tekst Wujkowy w stronę wierniejszego odwzorowania tych latynizmów (a także pośrednio grecyzmów i hebraizmów) leksykalnych, frazeologicznych oraz składniowych, które dały podstawę lwiej części biblizmów języka polskiego. Per saldo oznaczało to zatem większe przybliżenie polszczyzny biblijnej ku o wiele bogatszym i bardziej wyrobionym pod względem językowo-retorycznym wzorcom, co będzie mieć niebagatelne znaczenie dla ilościowych i jakościowych przemian i dalszych losów nie tylko biblijnej, ale też literackiej polszczyzny [Lewaszkiewicz 1992: 232-248]. Ośmielę się stwierdzić, iż w tym, nie w pełni zamierzonym procesie, tkwi jedno z głównych źródeł utożsamienia polszczyzny biblijnej z retorycznymi wzorcami stylu wysokiego. Naśladownictwo i podtrzymanie wielu z owych znamion tekstu Biblii Wujka przez Biblię gdańska dokonało się także w znacznym stopniu kosztem odejścia od wielu nowatorskich pomysłów językowo-translacyjnych jej wyznaniowych poprzedniczek, tj. Biblii brzeskiej oraz Biblii nieświeskiej. Proces ten w oczywisty sposób stał się więc źródłem dodatkowego rozszerzenia językowo-stylowego wzorca tekstu katolickiego na obszary konfesyjnie mu odmienne. Oznacza to również, że polszczyzna biblijna ostatecznie „nie poszła" za szerokim nurtem polszczyzny renesansowej, lecz ukonstytuowana została w znacznym stopniu na cechach nie w pełni należących do systemowych właściwości języka polskiego.

Przyjdzie także w tym miejscu skonstatować, że Biblia gdańska zamyka de facto staropolski okres poszukiwań i doświadczeń na polu rodzimej translatoryki biblijnej. Rok 1632 należy zatem przyjąć jako umowną cezurę wieńczącą pierwszą fazę w dziejach polszczyzny biblijnej, którą można określić jako kształtowanie się jej głównych zrębów i wyznaczników. Oba przekłady, tj. Biblię Wujka oraz Biblię gdańska, postrzegać należy jako te tłumaczenia, w których w znacznym stopniu kumuluje się całe w tym względzie doświadczenie wcześniejsze. Godzi się podkreślić i przypomnieć, że w tych najstarszych próbach transferowania ksiąg Pisma Świętego na grunt języka polskiego oraz wykształcania się jego biblijnych osobliwości stylistycznych pobrzmiewa także echo znaczącego udziału w tym procesie języka czeskiego, czego dowiodły liczne badania podejmowane w minionych latach przez uczonych zarówno polskich, jak i czeskich [Belcarzowa 2006; Kwilecka 2003c: 199-208; Kyas 1953: 112-124; Urbańczyk 1946].

Dla dziejów polszczyzny biblijnej za równie istotny, czy wręcz rozstrzygający, uznać należy fakt, który wiąże się z rolą i wielowiekową obecnością Biblii Wujka i Biblii gdańskiej w szerzej postrzeganej kulturze polskiej [Słowiński, red. 2013]. Jak dowodzą bowiem bliższe obserwacje, w odwołaniach biblijnych, po które sięgali najwybitniejsi polscy poeci i pisarze (Adam Mickie- 
wicz, Cyprian Norwid, Stanisław Wyspiański, Henryk Sienkiewicz), na równi dają się odnaleźć ślady stylizacyjnych odwołań do Biblii Wujka i do gdańskiej [Bieńkowska 1994: 162-170]. Warto także pamiętać, że liczbą wydań na przestrzeni XVII-XX wieku Biblia gdańska w pełni dorównywała Biblii Wujka. Z wypowiedzi zaś Czesława Miłosza wiemy, że to Biblia gdańska była najbardziej dostępnym poecie przekładem, z którego wyrastała szczególna wrażliwość noblisty na słowo [Miłosz 1994: 249]. Trudno jednakże o bardziej trafną i sugestywnie wyrażoną opinię na temat roli i miejsca tych przekładów od tej, która wyszła spod pióra Zygmunta Kubiaka, także tłumacza ksiąg biblijnych. W jednym z esejów ów wybitny znawca kultury antycznej pisze: „Mowa polska w Biblii Wujka, Biblii Gdańskiej zdumiewająco dźwiga potęgę i czule przechowuje czar stylu biblijnego obu Testamentów" [Kubiak 1993: 155].

Proces żywego oddziaływania obydwu omawianych przekładów zauważalny jest praktycznie do lat 70. XX stulecia, a podejmowane w ciągu wieków próby modernizacyjne względem ich editio princeps praktycznie nie objęły istotnych dla polszczyzny biblijnej płaszczyzn. W przypadku Biblii Wujka oddziaływanie to zacznie wygasać wraz z nowym, milenijnym tłumaczeniem katolickim Pisma Świętego, tj. Biblia Tysiąclecia (1965), które przejęło po thumaczeniu Wujkowym funkcję tekstu liturgicznego w Kościele w Polsce. $\mathrm{Z}$ kolei Biblię gdańska po blisko trzy i pół wieku w roli podstawowego przekładu dla polskich protestantów zastąpiła tzw. Biblia warszawska (1975). W tych czterech tłumaczeniach, układających się w symboliczny czworobok obejmujący niemal cztery stulecia (1599-1975), kryją się w moim przekonaniu główne źródła petryfikacji tych cech, które złożyły się ostatecznie na tradycyjny polski styl biblijny. Próba schematycznego zakreślenia tej centralnej dla dziejów polszczyzny biblijnej fazy daje się zatem przedstawić następująco:
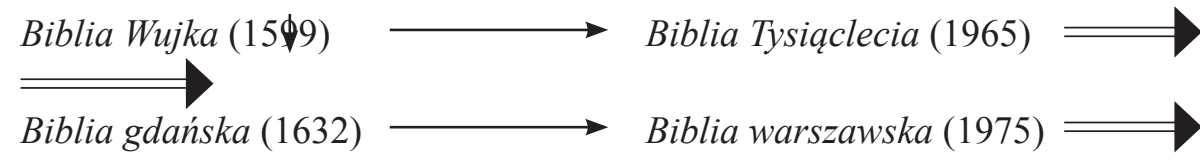

Daty ukazania się katolickiej Biblii Tysiąclecia oraz protestanckiej Biblii warszawskiej można zatem potraktować jako symboliczną cezurę zamykającą drugą z wyróżnionych faz w dziejach polszczyzny biblijnej i zarazem początek trzeciej, którą można nazwać fazą kontynuacji i przemian.

Otwiera się tu pole do zgoła osobnych rozważań, które w tym miejscu przyjdzie jedynie zasygnalizować. Wśród dotychczasowych prób opisu tego, co składa się na nowsze dzieje polszczyzny biblijnej i jej relacji względem doświadczeń historycznych, zazwyczaj wskazuje się na współistnienie dwóch 
przeciwstawnych nurtów: tradycjonalistycznego i antytradycjonalistycznego [Binek 2000: 211-218; Szczepińska 2005]. Kwestią istotną okazuje się w tym wypadku przede wszystkim ocena roli i sposobu odniesienia się obydwu wskazanych thumaczeń współczesnych do konfesyjnych antenatek, tj. Biblii Wujka oraz Biblii gdańskiej. W wypadku Biblii Tysiaclecia, mimo odredakcyjnie wyrażonej we wstępie do pierwszego wydania jednoznacznej deklaracji o odstąpieniu „od czcigodnej tradycji Wujkowej”, wyniki dotychczasowych badań filologicznych dają daleko idące podstawy, aby w tekście tego thumaczenia dostrzec mniej lub bardziej zamierzone próby podtrzymania wielu tradycyjnych wyznaczników polszczyzny biblijnej [Koziara 2016: 15-31, zob. tamże odnośna literatura]. Na szerszą uwagę w tym kontekście oczekuje z kolei drugie z thumaczeń, tj. protestancka Biblia warszawska, której wstępna ocena przypisuje kompromisowe odniesienie się do tradycji Biblii gdańskiej [Lisowski 2002: 123-140]. Wskazując z konieczności jedynie skrótowo na miejsce protestanckich translacji Pisma Świętego w nowszych dziejach polszczyzny biblijnej, godzi się także zwrócić uwagę na różnorodność oraz wielokierunkowość szeregu inicjatyw na tym polu. Nie ulega wątpliwości, że wiele spośród nich wzbogaciło polską translatorykę biblijną o nowe rozwiązania w dziedzinie metod przekładowych, takich jak przekład dynamiczny, filologiczny czy technika parafrazy zastosowana w odniesieniu do niepoetyckich ksiąg biblijnych. Nie sposób wreszcie nie zauważyć wkładu środowisk protestanckich w dziedzinie najnowszych, przełomowych prac nad ekumenicznym thumaczeniem Pisma Świętego na język polski.

Wskazując na wielokonfesyjne korzenie polszczyzny biblijnej / polskiego stylu biblijnego, trudno na koniec pominąć i nie docenić ogromnych zasług, jakie wniosły w XIX i XX stuleciu środowiska i stowarzyszenia protestanckie w dziedzinie upowszechnienia na równi wydań Biblii ks. Wujka i protestanckiej Biblii gdańskiej. Mowa tu przede wszystkim o roli wielce zasłużonego na tym polu Brytyjskiego i Zagranicznego Towarzystwa Biblijnego, w ramach działalności zarówno jego oddziału polskiego, jak i innych oddziałów zagranicznych [Enholc-Narzyńska 1994: 136-151].

\section{Uwagi końcowe}

Zaprezentowana powyżej próba oceny miejsca i znaczenia protestanckich thumaczeń Pisma Świętego w historii polszczyzny biblijnej pozwala na sformułowanie kilku wniosków natury ogólnej, w syntetyczny sposób odnoszących się do wyników dotychczasowych badań w tej dziedzinie bądź też wyrażających nieco odmienne niż dotychczas opinie w tym zakresie. Pochodną tego oglądu jest propozycja periodyzacji dziejów polszczyzny biblijnej, uwzględniająca 
jej trzy główne fazy rozwojowe. Pierwsza z nich obejmowałaby dokonania w dziedzinie polskiej literatury przekładowo-biblijnej od najstarszych zabytków średniowiecznych po złoty wiek polskiej Biblii, de facto zamykający się datami pełnego wydania Biblii Wujka oraz Biblii gdańskiej. Jako fazę drugą i zarazem centralną dla dziejów polszczyzny biblijnej uznać należy okres blisko czterowiekowego trwania Biblii Wujka w roli tekstu podstawowego dla katolików oraz Biblii gdańskiej w analogicznej roli dla ewangelików polskich, symbolicznie zamknięty datami pierwszych wydan Biblii Tysiąclecia oraz Biblii warszawskiej. Daty te z kolei należy postrzegać zarazem jako cezurę otwierającą trzecią, in statu nascendi fazę w dziejach polszczyzny biblijnej, którą można roboczo określić mianem fazy kontynuacji i przemian. We wszystkich fazach znaczący jest udział translacyjno-biblijnego dorobku protestantyzmu.

Jednym z najdalej idących wniosków, wyprowadzonym na podstawie dotychczasowych badań materiałowych, jest dość zgodne przeświadczenie, iż protestanckie przekłady Pisma Świętego doby reformacji i kontrreformacji otwarły in toto postrzeganą polszczyznę zarówno na obszary i właściwości języków biblijnych, jak też na renesansowe bogactwo mowy rodzimej. Dokonania te włączyły polską translatorykę biblijną w krąg nowoczesnych, opartych na naukowych podstawach metod przybliżania Pisma Świętego, zapoczątkowując ponadto wiele nowych rozwiązań typograficznych i edytorskich w tej dziedzinie (np. Biblia brzeska). Wbrew do niedawna wyrażanej opinii najstarsza faza kształtowania się wzorca polszczyzny biblijnej nie została jednak zdominowana przez jedną z tradycji, tym samym więc nie doszło do rozejścia się na jej dwie drogi: katolicką i protestancką. Podjęte próby ujęć konfrontatywnych dość jednoznacznie pokazują bowiem, iż mająca szczególny status i wielowiekowe oddziaływanie katolicka Biblia Wujka w kształcie z roku 1599 nosi ślady rozlicznych odwołań do wcześniejszych dokonań na polu rodzimej translatoryki, przejmując i sankcjonując zarazem szereg spośród tych właściwości językowych swoich poprzedników, które złożyły się ostatecznie na stylowy inwariant polszczyzny biblijnej. Natomiast protestancka Biblia gdańska z początku XVII wieku, naśladując wiele właściwości translacyjnych i stylowych Biblii Wujka, przyczyniła się z kolei w znacznej mierze do konfesyjnego poszerzenia owego wzorca. Jego charakterystyczną cechą, będącą pochodną dominującej w polskiej translatoryce biblijnej metody thumaczeń dosłownych, jest obecność wielu systemowych właściwości języków biblijnych, tj. hebraizmów i grecyzmów leksykalnych, składniowych, frazeologiczno-formulicznych oraz stylistyczno-retorycznych. Tak znaczący udział w tekstach rodzimych thumaczeń Pisma Świętego cech systemowo obcych polszczyźnie ogólnej, odziedziczonych z języków o wyższym prestiżu i bogat- 
szym potencjale, daje podstawy do utożsamienia polszczyzny biblijnej z wzorcami retorycznego stylu wysokiego, kryjącego wiele śladów języka i kultury semickiej, helleńskiej, a także łacińskiej. Nie ulega przy tym wątpliwości, że w dziele narodzin i kształtowania się biblijnej odmiany stylowej języka polskiego udział ma wielowiekowa tradycja tłumaczeń zarówno katolickich, jak i protestanckich. Tezę tę, kryjącą w sobie doniosły wymiar filologiczny, godzi się przy tak niecodziennej okazji, jaką jest rocznica 500-lecia reformacji, po raz wtóry wypowiedzieć szczególnie dobitnie.

\section{Bibliografia}

\section{Teksty źródłowe}

1551 - Ewangelia według św. Mateusza, przekład Stanisława Murzynowskiego, Kró-

lewiec 1551, edycja i oprac. Izabela Winiarska-Górska (za: https://ewangelie. uw.edu.pl/teksty).

1556 - Nowy Testament, tzw. Szarffenbergera, Kraków 1556, edycja i oprac. Szymon

Gruda (za: https://ewangelie.uw.edu.pl/teksty).

1561 - Biblia to jest Księgi Starego i Nowego Zakonu polski język [...] nowo wyłożone,

Kraków 1561 (Biblia Leopolity).

1563 - Biblia Święta, to jest ksieggi Starego i Nowego Zakonu, Brest 1563, red. Hans

Rothe, Friederik Scholz, Biblia Slavica, S. II, Polnische Bibeln, t. 2, cz. 1: Stary

Zakon; cz. 2: Księgi Nowego Testamentu. Kommentare, Ferdinand Schöningh

Verlag, Paderborn 2001 (Biblia brzeska).

1570 - Nowy Testament w przekładzie Szymona Budnego, Nieśwież 1570, edycja

i oprac. Ewelina Kwapień (za: https://ewangelie.uw.edu.pl/teksty).

1572 - Biblia. To jest Ksiegi Starego i Nowego Przymierza, przeł. Szymon Budny,

Nieśwież, Zasław 1571-1572, red. Hans Rothe, Friederik Scholz, Biblia Slavica,

S. II, Polnische Bibeln, t. 3, Ferdinand Schöningh Verlag, Paderborn 1994 (Biblia nieświeska).

1577 - Nowy Testament w przekładzie Marcina Czechowica, Kraków 1577, edycja

i oprac. Aneta Korycińska, przy współpracy Izabeli Winiarskiej-Górskiej (za:

https://ewangelie.uw.edu.pl/teksty).

1593 - Nowy Testament w przekladzie ks. dr Jakuba Wujka T.J. z roku 1593, wstępem

i uwagami poprzedził ks. dr Władysław Smereka, Kraków.

1599 - Biblia to jest Księgi Starego i Nowego Testamentu, [...] na polski język znowu

z pilnościa przełożone [...], Kraków 1599 (Biblia Wujka) (za: http://www.wbc. poznan.pl/dlibra/). 
1632 - Biblia Święta. To jest Księgi Starego i Nowego Przymierza [...], na polski pilnie i wiernie przetlumaczone, Gdańsk 1632 (Biblia gdańska) (za: http://www. bibliagdanska.pl/).

1965 - Pismo Święte Starego i Nowego Testamentu w przekładzie z języków oryginalnych, opracował zespół biblistów polskich pod redakcją benedyktynów tynieckich, Poznań 1965-2000 (Biblia Tysiąclecia).

1975 - Biblia to jest Pismo Święte Starego i Nowego Testamentu. Nowy przekład z języków hebrajskiego i greckiego opracowany przez Komisję Przekładu Pisma Świętego, Warszawa 1975 (Biblia warszawska).

\section{Słowniki}

SXVI - Słownik polszczyzny XVI wieku, t. 1-34, red. Maria Renata Mayenowa, Franciszek Pepłowski, Wrocław 1966-2010.

\section{Literatura}

Belcarzowa Elżbieta (2006), Polskie i czeskie źródła przekładu Biblii Leopolity, Wydawnictwo Lexis, Kraków.

Bieńkowska Danuta (1992), Styl językowy przekładu Nowego Testamentu Jakuba Wujka (na materiale czterech Ewangelii), Wydawnictwo Uniwersytetu Łódzkiego, Łódź.

Bieńkowska Danuta (1994), Odbicie stylu przekładu Biblii J. Wujka w literaturze polskiej, w: Jan Jakub Wujek ttumacz Biblii na język polski. W czterechsetna rocznice wydania Nowego Testamentu 1593-1993, red. Maria Kamińska, Archidiecezjalne Wydawnictwo Łódzkie, Łódź, s. 162-170.

Bieńkowska Danuta (2002), Polski styl biblijny, Archidiecezjalne Wydawnictwo Łódzkie, Łódź.

Bieńkowska Danuta, Umińska-Tytoń Elżbieta (1994), Polszczyzna Biblii gdańskiej na tle XVI-wiecznych przekładów biblijnych, w: Polszczyzna regionalna Pomorza (zbiór studiów) 6, red. Kwiryna Handke, Slawistyczny Ośrodek Wydawniczy, Warszawa, s. 7-15.

Bieńkowska Danuta, Umińska-Tytoń Elżbieta (2017), Rozważania wokół leksemu biblizm, „Acta Universitatis Lodziensis. Folia Linguistica”, t. 51, nr 2, s. 27-39.

Binek Paweł (2000), O współczesnych polskich przekładach biblijnych świadomie nawiazujacych do tradycyjnego stylu biblijnego, w: Inspiracje chrześcijańskie w kulturze Europy, red. Ewa Woźniak, Archidiecezjalne Wydawnictwo Łódzkie, Łódź, s. 211-218.

Buchwald-Pelcowa Paulina (1994), Nad psalmami i psatterzami polskimi XVI wieku, w: Nurt religijny w literaturze polskiego średniowiecza i renesansu, red. Stefan Nieznanowski, Janusz Pelc, KUL, Lublin, s. 243-262. 
Budny Szymon (1994), Do czytelnika, w: Biblia. To jest Księgi Starego i Nowego Przymierza, przeł. Szymon Budny, Nieśwież, Zasław 1571-1572, red. Hans Rothe, Friederik Scholz, Biblia Slavica, S. II, Polnische Bibeln, t. 3, Ferdinand Schöningh Verlag, Paderborn, s. 17.

Chlebda Wojciech (1998), Biblizmy języka rosyjskiego. Koncepcje opisu leksykograficznego, w: Biblia w literaturze i folklorze narodów wschodniosłowiańskich, red. Ryszard Łużny, Danuta Piwowarska, Towarzystwo Autorów i Wydawców Prac Naukowych Universitas, Kraków, s. 15-33.

Chlebda Wojciech (2005), Biblizmy jako skrzydlate jednostki polszczyzny w: tegoż, Szkice o skrzydlatych słowach. Interpretacje lingwistyczne, Wydawnictwo Uniwersytetu Opolskiego, Opole, s. 209-251.

Czerski Janusz (1997), Wpływ języka hebrajskiego i aramejskiego na nowotestamentalna greke, w: Problemy frazeologii europejskiej II, Frazeologia a religia, red. Andrzej M. Lewicki, Wojciech Chlebda, Energeia, Warszawa, s. 335-341.

Długosz-Kurczabowa Krystyna (2007), Biblizmy w języku staropolskim, w: tejże, Szkice z dziejów języka religijnego, Wydział Polonistyki Uniwersytetu Warszawskiego, Warszawa, s. 155-174.

Enholc-Narzyńska Barbara (1994), Teksty biblijne w przekładzie ks. Jakuba Wujka, ich wydania i rozpowszechnianie przez Towarzystwo Biblijne $w$ Polsce $w$ XIX i XX wieku, w: Jan Jakub Wujek. Ttumacz Biblii na język polski. W czterechsetna rocznice wydania Nowego Testamentu 1593-1993, red. Maria Kamińska, Archidiecezjalne Wydawnictwo Łódzkie, Łódź, s. 136-151.

Frankowski Janusz (1974), Dlaczego trzeba było dokonać nowego przekładu Biblii?, „Znak”, nr 235, s. 63-82.

Głowiński Michał i in. (1988), Słownik terminów literackich, wyd. 2 poszerz. i popr., Zakład Narodowy im. Ossolińskich - Wydawnictwo, Wrocław.

Godyń Jan (2006), Wstęp, w: tegoż, Od Adama i Ewy zaczynać. Mały słownik biblizmów języka polskiego, wyd. 2 popr., uzup. i rozszerz., Oficyna Wydawnicza Rytm, Warszawa, s. 6-18.

Górski Konrad (1962), Zagadnienie słownictwa reformacji polskiej, w: Odrodzenie w Polsce, t. 3: Historia języka, cz. 2, red. Maria Renata Mayenowa, Zenon Klemensiewicz, Państwowy Instytut Wydawniczy, Warszawa, s. 233-279.

Jezierska J. Ewa (2009), Status i wyznaczniki stylu biblijnego, w: Polszczyzna biblijnamiędzy tradycją a współczesnościa, t. 1, red. Stanisław Koziara, Wiesław Przyczyna, Wydawnictwo Diecezji Tarnowskiej Biblos, Tarnów, s. 9-17.

Kępińska Alina, Składnia XVI-wiecznych przekładów Ewangelii na język polski, https:// ewangelie.uw.edu.pl/files/skladnia.pdf [dostęp: 10 marca 2018]. 
Kossowska Maria (1961), Werbalizm jako metoda przekładu Pisma św. (szkic na podstawie tekstu Nowego Testamentu), „Roczniki Teologiczno-Kanoniczne”, t. 8, z. 4, s. 5-32.

Kosowska Maria (1968), Biblia w języku polskim, t. 1, Księgarnia Świętego Wojciecha, Poznań.

Kosowska Maria (1969), Biblia w języku polskim, t. 2, Księgarnia Świętego Wojciecha, Poznań.

Koziara Stanisław (2002), Rola Biblii Gdańskiej w kształtowaniu stylowej odrębności polszczyzny biblijnej, „Myśl Protestancka”, t. 3-4, s. 69-80.

Koziara Stanisław (2009a), Frazeologia biblijna w języku polskim, wyd. 2 popr., Oficyna Wydawnicza Leksem, Lask.

Koziara Stanisław (2009b), Polszczyzna biblijna w poszukiwaniu wzorca stylowego. Doświadczenia $i$ współczesność, w: Polszczyzna biblijna - między tradycja a współczesnościa, t. 1, red. Stanisław Koziara, Wiesław Przyczyna, Wydawnictwo Diecezji Tarnowskiej Biblos, Tarnów, s. 19-33.

Koziara Stanisław (2009c), Tradycyjne biblizmy a nowe polskie przekłady Pisma Świętego, (ujęcie filologiczno-normatywne), Kraków.

Koziara Stanisław (2013), Rola Biblii Jakuba Wujka w dziejach kultury polskiej, w: Biblia Jakuba Wujka w życiu i kulturze narodu polskiego, red. Roman Słowiński, Polska Akademia Nauk, Poznań, s. 41-64.

Koziara Stanisław (2015), The current state of research by Polish linguists on the Brest Bible: an overview, „Reformation \& Renaissance Review”, t. 17, nr 1, s. 63-72.

Koziara Stanisław (2016), Biblia Tysiaclecia wobec tradycji polszczyzny biblijnejuwagi jubileuszowe, ,Język Polski”, z. 4, s. 15-31.

Koziara Stanisław, Wiesław Przyczyna, red. (2009), Polszczyzna biblijna - między tradycją a współczesnościa, t. 1-2, Wydawnictwo Diecezji Tarnowskiej Biblos, Tarnów.

Koziara Stanisław (2017), Z osobliwości językowych warsztatu przekładowego „Biblii brzeskiej” (zagadnienia wybrane), „Annales Universitatis Paedagogicae Cracoviensis. Studia Linguistica", t. 12, s. 158-169.

Kubiak Zygmunt (1993), Przestrzeń dziet wiecznych. Eseje o tradycji kultury śródziemnomorskiej, Znak, Kraków.

Kwilecka Irena (2003a), Staropolskie przektad Biblii i ich zwiazki z biblistyka europejska. Zarys problematyki, w: tejże, Studia nad staropolskimi przekładami Biblii, UAM. Wydział Teologiczny, PAN Instytut Slawistyki, Poznań, s. 209-230.

Kwilecka Irena (2003b), Staropolskie przekłady Biblii jako czynniki sprawcze zmian językowych, w: tejże, Studia nad staropolskimi przekładami Biblii, UAM. Wydział Teologiczny, PAN Instytut Slawistyki, Poznań, s. 253-263. 
Kwilecka Irena (2003c), Średniowieczna Biblia czeska a staropolskie przekłady biblijne (zarys problematyki badawczej), w: tejże, Studia nad staropolskimi przekładami Biblii, UAM. Wydział Teologiczny, PAN Instytut Slawistyki, Poznań, s. 199-208.

Kwilecka Irena (2003d), Z dziejów przekładu pierwszej polskiej Biblii protestanckiej, w: tejże, Studia nad staropolskimi przekładami Biblii, UAM. Wydział Teologiczny, PAN Instytut Slawistyki, Poznań, s. 335-352.

Kyas Vladimír (1953), Za českou předlohou staropolské bible, „Slavia”, z. 2, s. 112-124. Leszczyński Rafał (2001), Ewangelickie przektady Nowego Testamentu w szesnastowiecznej Polsce, w: Nowy Testament $w$ dziejach i kulturze Europy, red. Tomasz Jaworski, Wiesław Pyżewicz, Wydawnictwo Szkoły Nauk Humanistycznych i Społecznych Uniwersytetu Zielonogórskiego, Zielona Góra, s. 133-142.

Lewaszkiewicz Tadeusz (1992), Rola przekładów Biblii w formowaniu języków literackich europejskiego kregu kulturowego, w: Biblia a kultura Europy, t. 1, red. Maria Kamińska, Eliza Małek, Wydaw. Uniwersytetu Łódzkiego, Łódź, s. 232-248.

Lisowski Tomasz (2002), Język Biblii warszawskiej, wspótczesnego protestanckiego przektadu Pisma św. wobec tradycji, w: Język polski. Wspótczesność, historia, t. 2, red. Władysława Książek-Bryłowa, Henryk Duda, Towarzystwo Naukowe Katolickiego Uniwersytetu Lubelskiego, Lublin, s. 123-140.

Lisowski Tomasz (2010), Sola Scriptura. Leksyka Nowego Testamentu „Biblii gdańskiej" (1632) na tle porównawczym. Ujęcie kwantytatywno-dystrybucyjne, Wydawnictwo Rys, Poznań.

Łuczak Arleta (2014), Najstarsze stowiańskie przektady Biblii w niemieckiej serii „Biblia Slavica”, „Nauka”, nr 2, s. 135-150.

Matuszczyk Bożena (2002), Biblia Gdańska (1632) wobec wzorca polskiego stylu biblijnego, „Myśl Protestancka”, t. 3-4, s. 81-86.

Migdał Jolanta, Piotrowska K. Agnieszka (2009), Konserwatyzm językowy jako cecha przekładów biblijnych, w: Polszczyzna biblijna - między tradycja a wspótczesnościa, t. 1, red. Stanisław Koziara, Wiesław Przyczyna, t. 1, Wydawnictwo Diecezji Tarnowskiej Biblos, Tarnów, s. 313-322.

Miłosz Czesław (1994), Ziemia Ulro, Społeczny Instytut Wydawniczy „Znak”, Kraków.

Piela Marek (2003), Grzech dostowności we wspótczesnych polskich przekładach Starego Testamentu, Wydawnictwo Uniwersytetu Jagiellońskiego, Kraków.

Rospond Stanisław (1962), Język Renesansu a Średniowiecza na podstawie literatury psalterzowo-biblijnej, w: Odrodzenie w Polsce, t. 3: Historia języka, cz. 2, red. Maria Renata Mayenowa, Zenon Klemensiewicz, Państwowy Instytut Wydawniczy, Warszawa, s. 61-181. 
Siatkowska Ewa (2013), Imiesłowy w Biblii brzeskiej i Biblii Wujka a kształtowanie się polskiego stylu biblijnego, w: Biblia brzeska. Historia-język-teologia, red. Rafał Marcin Leszczyński (junior), Wydawnictwo Fot-Graf, Łódź, s. 39-54.

Słowiński Roman, red. (2013), Biblia Jakuba Wujka w życiu i kulturze narodu polskiego, Polska Akademia Nauk, Poznań.

Szczepińska Bożena (2005), Ewangelie tylekroć tlumaczone... Studia o przekładach i przekładaniu, Wydawnictwo Uniwersytetu Gdańskiego, Gdańsk.

Szurek Marzena Maria (2013), Z dziejów polszczyzny biblijnej. Biblia Wujka (1599) a Biblia gdańska (1632). Studium komparatywne, Collegium Columbinum, Kraków.

Urbańczyk Stanisław (1946), Z dawnych stosunków językowych polsko-czeskich, cz. 1: Biblia królowej Zofii a staroczeskie przekłady Pisma Świętego, „Rozprawy Wydziału Filologicznego Polskiej Akademii Umiejętności”, t. 67, nr 2.

Walczak Bogdan (2013), Rola przekładu Biblii autorstwa Jakuba Wujka $w$ dziejach języka polskiego, w: Biblia Jakuba Wujka w życiu i kulturze narodu polskiego, red. Roman Słowiński, Polska Akademia Nauk, Poznań, s. 65-81.

Winiarska Izabela (2004), Stownictwo religijne polskiego kalwinizmu od XVI do XVIII wieku na tle terminologii katolickiej, Semper, Warszawa.

Winiarska-Górska Izabela (2009), Język, styl i kulturowa rola szesnastowiecznych protestanckich przekładów Nowego Testamentu na język polski: między nowatorstwem a tradycja, w: Polszczyzna biblijna - między tradycja a współczesnościa, red. Stanisław Koziara, Wiesław Przyczyna, t. 1, Wydawnictwo Diecezji Tarnowskiej Biblos, Tarnów, s. 279-312.

Wujek Jakub, ks. (1966), Przedmowa do Czytelnika, w: Nowy Testament w przekładzie ks. dr Jakuba Wujka T.J. z roku 1593, wstępem i uwagami poprzedził ks. dr Władysław Smereka, Polskie Towarzystwo Teologiczne, Kraków, s. 51-75.

Źródła elektroniczne

https://ewangelie.uw.edu.pl/teksty

https://ewangelie.uw.edu.pl/files/skladnia.pdf

http://www.bibliagdanska.pl/

http://www.wbc.poznan.pl/dlibra/ 


\section{Stanisław Koziara}

\section{The place and significance of Protestant Bible translations in the history of biblical Polish language (an outline of the description)}

The paper is an attempt at the synthetic look into this part of Polish bible translation heritage, whose integral part are the translations of the Bible in Protestant circles. The fundamental thesis of the work is based on the statement that Protestant translations of the Bible into Polish contributed substantially to its quantitative and qualitative evolution, as well as constitute one of the main sources of the development of the biblical stylistic variant of Polish. The greatest attention has been paid to the role and significance of Polish Bible translations in this process, which were made in the times of Reformation and Counter-Reformation, as well as to the attempt at indicating some links that appeared between the most important Catholic and Protestant translations of this period. The paper provides numerous references to previous views on the investigated issues, and provides a range of new suggestions, e.g. a periodization of the history of biblical Polish language, as well as indicates the need for further work in this field.

Keywords: Protestant Bible translations; biblical Polish language; the history of the Polish language.

prof. dr hab. Stanisław Koziara - Uniwersytet Pedagogiczny im. Komisji Edukacji Narodowej w Krakowie; zainteresowania naukowe: historyczne i współczesne problemy polskiego języka religijnego, dziedzictwo biblijne w języku polskim, stylistyka, frazeologia. 